\title{
TIMOR LESTE'S ACCESSION TO ASEAN 2011: AN ANALYSIS OF INTERNATIONAL FACTORS
}

\author{
Puguh Toko Arisanto
}

\begin{abstract}
After gaining its independence in 2002, Timor Leste struggled for joining ASEAN's membership. Timor Leste changed foreign policy orientation from PIF to ASEAN. Then, Timor Leste had put its decision in 2011 which officially enrolled as member of ASEAN. This article seeks to analyze Timor Leste's decision to join ASEAN's membership. The authors sought to find the answers by using foreign policy decision-making model. This article focused on international factors which are derived from two important variables namely international context and economic and military conditions. The authors found from international context that Timor Leste decided to join ASEAN due to ASEAN's attractiveness as prospective regional organization and strong support emanating from Indonesia as an influential state regionally. Economic conditions comprise close economic relations of Timor Leste with ASEAN countries. Military conditions are analyzed from Timor Leste's military capability amidst neighbor's military capability and its need to collective security.
\end{abstract}

Keywords: Foreign Policy, Decision-Making Model, International Context, Economic and Military Conditions.

\section{INTRODUCTION}

The accession of Timor Leste (East Timor) to become a member of the Association of Southeast Asian Nations (ASEAN) still encountered obstacles up to 2019. Regardless of different identity matters with ASEAN countries, Timor Leste had willy nelly to gradually face various obstacles such as a rejection of Singapore, domestic problems (social, politics, economic and development) and doubted capability to attend all meetings between members and to fulfill all member's obligations (Swastika, 2016). To cope with them indirectly, 
Timor Leste had undertaken various diplomatic efforts to convince all ASEAN members. Timor Leste had conducted multi track diplomacy through channels of inter-governments and non-governments, academic, funding and communication media (Xavier, 2016).

Timor Leste's accession to ASEAN membership is not a new issue in the regionally political constellation of the Southeast Asia organization. It was long before making up its mind to apply for ASEAN membership in 2011, Timor Leste had shortly undergone a change in its foreign policy orientation towards ASEAN after its independence in 2002. In addition, Timor Leste's participation in regional organization member was a controversial issue because Timor Leste could join as a member both in ASEAN and Pacific Island Forum (PIF) (Strating, 2019). Under this circumstance, Timor Leste had to decide on its foreign policy, whether to join (as a member) ASEAN or PIF given that it is not allowed to become a member in two regional organizations simultaneously.

Timor Leste's tendency to join PIF membership occurred since postreferendum 1999 before its independence. There were several factors underlying Timor Leste to join PIF membership:

1. Geographical and political proximity to one of PIF countries, Australia. Timor Leste's close relations with Australia occurred during Timor Leste's independence. Before the referendum 1999 took place, Australia had clearly announced its support for Timor Leste that initiated to separate from Indonesia through print and electronic media. After the polls, Australia also played a vital role in the process of Timor Leste's independence by mobilizing international support and helping the United Nations (UN) secure the domestic conditions of Timor Leste. Until 2002, Australia had deployed around 5500 soldiers as peacekeepers (Joseph \& Hamaguchi, 
2. Similarity in terms of cultural background with most Pacific island countries as Melanesian identity indicates that Timor Leste has emotional ties and moral closeness with Pacific Island countries.

3. Institutional support from PIF countries at the process of independence was proven by a meeting in 1999. The results of the meeting discussed the institutional support of PIF as regional organization for Timor Leste's independence (Wuryandari, 2011).

Compared to ASEAN countries, the roles of PIF countries in the process of Timor Leste's independence were clearly greater than those of ASEAN countries. In the aftermath of 1999 referendum, only three ASEAN countries contributed to peace mission in Timor Leste (Thailand, Philippines \& Singapore). Thailand and Philippines contributed in deploying battalions to enforce the peace mission. Singapore sent some assistance in the form of medicines and other logistics (Horta, 2000). Assistances from the three ASEAN countries were not in a point of supporting Timor Leste's independence, bearing in mind that support for Timor Leste's independence would hurt Indonesia. In addition, on the other hand Timor Leste also has a different cultural background with ASEAN countries so that emotional and moral closeness is less compared to Timor Leste's proximity to Pacific Island Nations.

Timor Leste's desire to be part of the PIF was also evidenced by the statements of famous Timor Leste's figures. One of them was a statement of Ramos Horta, a big figure who was an exile and an international envoy of Timor Leste's prominent political parties when visiting a fundraising lunch in Sydney, Australia in 1999. He said "We are one of the South Pacific nations (prior to PIF), not part of ASEAN (Azhari, 2011) which means Timor Leste is part of Pacific Island countries not ASEAN. Again, in the same year when Ramos Horta visited Manila, the Philippines, Ramos 
stated" It is far more important for us to join the South Pacific Forum than ASEAN "(Miller, 1999). He added that by joining PIF, Timor Leste would enhance strategic relations with Australia and New Zealand and increase their relationship with Pacific Islands.

However, after its independence and the appointment of Xanana Gusmao as President, Timor Leste's desire to lead to PIF proved shortly. The newly independent state apparently no longer rejected its desire to be part of ASEAN. Timor Leste had changed its foreign policy orientation from PIF to ASEAN. After becoming an ASEAN observer in 2002, a few years later Timor Leste showed a strong political will to become an important part of ASEAN, not only as an observer but as a full member of ASEAN. Evidently, Timor Leste attended several ASEAN Summit meetings despite its observer status. After Ramos Horta served as second President of Timor Leste, Timor Leste opened an ASEAN national secretariat in Dili in 2009 (Thejakartapost, 2009). Finally, in 2011 Timor Leste officially submitted membership applications to ASEAN. In another word, Timor Leste officially decided to join ASEAN. This paper seeks to explain the reasons underlying Timor Leste's accession to become a member of ASEAN in 2011 by using a model of foreign policy making. It addresses to international factors comprising variables of international context and economic and military conditions of Timor Leste.

\section{LITERATURE REVIEW}

\section{Theory of Foreign Policy-Decision Making}

Foreign policy can be interpreted as activities of state actors in the form of actions, reactions and interactions executed in the external environment (Evans \& Newnham, 1998). At foreign policy analysis level, Nau (2012) stated that policy makers usually consider the combination between domestic level and systemic process or international level. This also means that the policy makers consider two-level games as so explained by Robert Putnam (Putnam, 1988). In line with Putnam, William 
D Coplin elaborated widely that international and domestic factors were important inputs in foreign policy decision making. Furthermore, Coplin (2003) added that there are several considerations for policy makers to issue foreign policies constituting accumulation of domestic and international factors. Those are domestic politics (addressing to policy influencers), international context and economic and military conditions. This can be seen from the following chart:

Chart 1. Foreign Policy Decision-Making Model

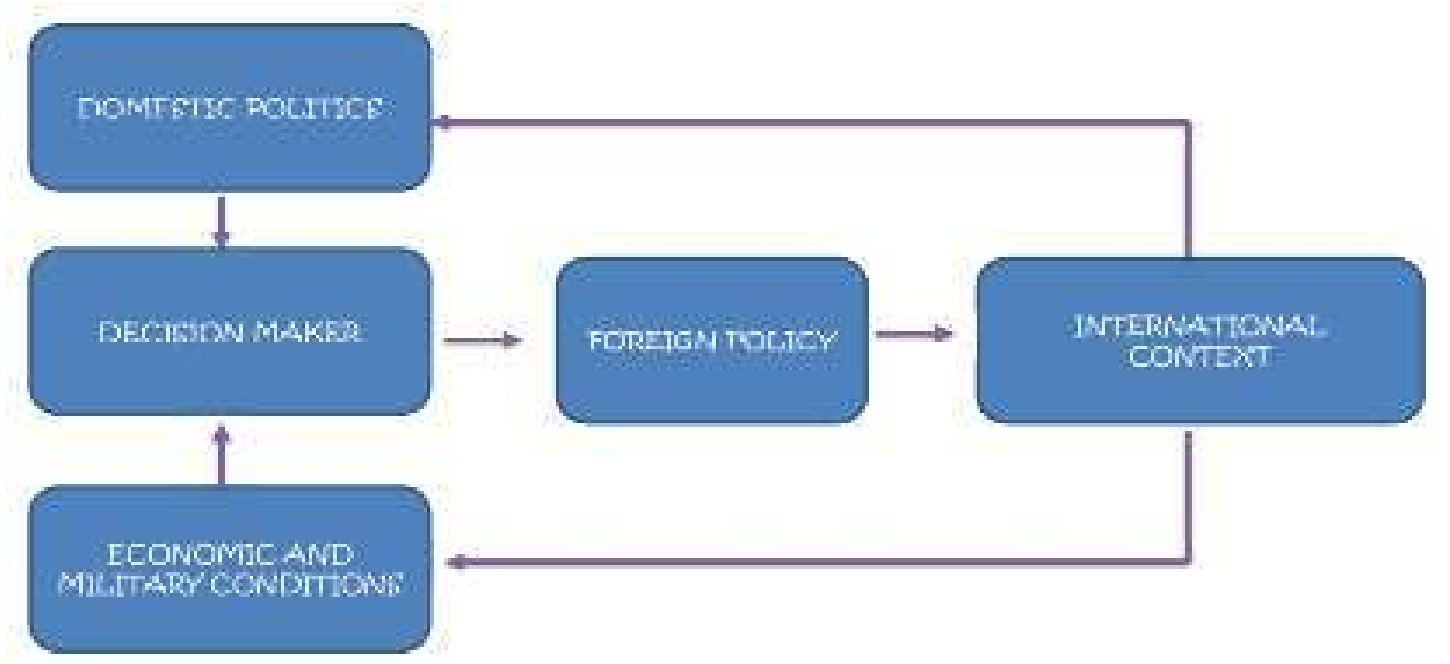

Source: Coplin, 2003

International context can also be interpreted as an international environment. Each country consists of a location it occupies in a system and political relations with other countries in the past, present and future. (Coplin, 2003). The international context is also related to policies and actions of other countries or international entities that can provide certain political responses to the domestic environment of a state. This means the role of the international context in the process of foreign policy decision making is as a stimulus for both decision makers and policy influencers. There are at least two elements of the international context in terms of foreign policy decisions: geographical and political elements. 
Geographical element is one of the important factors to discuss on decision making process referring to geographical and geopolitical conditions of state or region. Meanwhile, the political element as an international context comprising political relations between states determines how a state may proceed its foreign policy. Analyses of the international context on political elements can also be centered on a regional region because the international context is generally composed of patterns of relations between countries within a region. Foreign policy decision makers in a region, however, pay attention to the relations between the countries of the region whether to pose a conflict, competition or collaboration with the other regional actors in their region (Coplin, 2003).

Domestic politics refers to the role of policy influencers in influencing policy makers. Here, policy makers can be identified as President, Prime Miniter or Minister. Coplin elaborated that policy influencers consist of bureaucratic, partisan, interest and mass influencers. In many ways, the four groups have different views with policy makers in seeing the international situations and issues. They consistently with various means seek to influence policy makers to in turn meet their demands.

Economic and military conditions are important considerations in the process of foreign policy making. Policy makers need to consider the economic capabilities of their state. In this context, policy makers also put their attention on how their country's relations with other countries in the economic matters such as trade and investment. In military contexts, policy makers evaluate their military capabilities when compared to other countries, especially with neighboring countries that have the potential to be a threat to its military security.

Considering the number of variables with their indicators, the focus of this paper's discussion will only address to international factors. From the three variables above, the authors propose the international context and 
economic and military conditions as variables representing international factors.

\section{DISCUSSIONS}

\section{International Context:}

\section{ASEAN'S Attractiveness as Prospective Regional Organization}

Southeast Asia was heralded as one of the most prospective regions in the world by many. Inhabiting in Southeast Asia, ASEAN as regional organization formed in 1967, put economic cooperations and partnerships as one of its primary agendas. To embody economic developments in the region, ASEAN countries had forged a path towards economic integration by initiating Preferential Trade Agreement (PTA) and the ASEAN Free Trade Area (AFTA) before 2000. These two mechanisms are the embryo for realizing economic integrations of Southeast Asia countries in order to create the Southeast Asia region towards the formation of a single market and competitive production base (ADBI, 2014).

ASEAN countries has slowly but surely created the Southeast Asia region as one of the most dynamic regions in the world (OECD, 2009). ASEAN consisting of 10 countries (Indonesia, Malaysia, Philippines, Singapore, Laos, Cambodia, Brunei, Myanmar, Vietnam and Thailand) has shown progressive region, making it the center of global attention. Although their economic levels vary, the average growth in this region is quite high. Economic growth before 2011 reached 6\%-6.5\% and this exceeds percentages of global economic growth. In addition, ASEAN has made the Southeast Asia region the world's most important region with the fastest growth in the world and accounted for around 6\% of total global trade in the world (Singham \& Harihara, 2011). ASEAN countries also have strong economic ties proven by trade growth between ASEAN countries (intra- 
regional) which continues reaching 25\% of total ASEAN's trade since 2007 (Ananda, 2019).

In a geographical context, ASEAN has played a significant role in the global economy due to its strategic geographical location, dynamic global trade across the region and dynamic population growth as potential consumers of industrial products. In addition, FDI or Foreign Direct Investment entering the regions is increasingly large and has created a single market with a potential consumer of more than 600 million people. In 2010, FDI residing in the region reached US $\$ 75.8$ billion and showed a very impressive growth with more than $100 \%$ of percentage from the previous years (ASEAN, 2011). In another context, the region's proximity to predominant markets such as China strengthens ASEAN's status as an important player in global trade and as a production base for many multinational companies.

Some observers of world economies show optimism about the progress of ASEAN as a regional organization that has an important position in the global economy. Some of these points refer to total Gross Domestic Product (GDP) of ASEAN countries that account for triple to US\$ 3 trillion by 2017. ASEAN countries are expected to be primary destination of FDI for foreign countries not only attributable to a stable macroeconomic environment but also abundant markets and resources (ASEAN, 2011). With potentials for regional progress that continues to increase, it is not surprising that many countries outside ASEAN will throng to the region as their main destination for economic cooperations such as ASEAN plus 3 (South Korea, Japan and China), ASEAN-India Free Trade Area (AIFTA) and ASEAN-Australia-New Zealand Free Trade Area (AANZFTA).

As time goes by, ASEAN has experienced an unprecedented development. The development of ASEAN has entered a new phase since the adoption of a vision that aspired the ASEAN community making ASEAN as an open, peaceful, mutually bound and prosperous community (ASEAN, 2012). Through the establishment of this ASEAN community, ASEAN 
countries will further strengthen ASEAN integration and deliver this regional organization to be increasingly perfect with its blueprint, the ASEAN Community 2015. One of the blueprints is ASEAN Economic Community (AEC) which is predicted as a perfect manifestation of ASEAN in accordance with ASEAN goals stated in the charter ASEAN No. 5. The charter basically envisages to create a single market and production base that is stable, prosperous, highly competitive, and economically integrated through effective facilitation for trade and investment. It resides a free flow of goods, services, investment, labor and capital.

With some of the facts above, Timor's interest in accessing to ASEAN membership will no longer surprise at all. Timor Leste will be on the right track aside from attractiveness of ASEAN, several ASEAN countries also have unfavorable economic conditions as Timor Leste. By joining as a member of ASEAN, Timor Leste will work closely with ASEAN countries which are mostly as developing countries to advance their respective economies. This could be a good steppingstone for Timor Leste to step into a better economy.

\section{Strong Support of Indonesia as An Influential State in Southeast Asia}

It is blatantly stated in article 6 of ASEAN Charter that to join ASEAN membership, aside from geographical proximity, the applicant (state) must obtain recognitions of all members. Therefore, implicitly before being recognized as a member of ASEAN, Timor Leste must at least obtain political supports from ASEAN countries first. Of the several ASEAN countries, Indonesia is the most vital country in terms of supporting Timor Leste to enter ASEAN membership.

As a former country and closest region to Timor Leste geographically, Indonesia is assumed a strategic gateway for Timor Leste to get through international activities. Despite feeling disappointed after Timor Leste had separated from its territory through a 1999-referendum, Indonesia has come to be the most consistent and worthy in supporting Timor Leste's 
accession to ASEAN. These supports were carried out through statements by Indonesian officials as well as supportive actions to facilitate Timor Leste to become the $11^{\text {th }}$ member of ASEAN.

Indonesia's support began in 2000 (before Timor Leste's independence) when Ramos Horta as an international ambassador visited Indonesia in the Abdurrahmad Wahid administration. Abdurrahmad Wahid, popularly known as Gusdur became a central figure who was very zealous to support if Timor Leste wished to join ASEAN (Horta, 2000). Gusdur was looking forward to seeing Timor Leste in ASEAN membership as soon as possible to enhance Timor Leste's international diplomacy, strengthen Timor Leste's position when confronting the international community and prevent interference from another state.

Indonesian supports were also carried out in international forums. As Timor Leste expressed its desire to become a member of ASEAN, several ASEAN countries expressed their rejection or objection. Timor Leste obtained objections from Myanmar because Timor Leste criticized democratic conditions and supported pro-democracy fighters, Aung San Suu Kie (Soares \& Costa, 2003). Cambodia also did not accept Timor Leste's membership for unclear reasons. While Singapore considered that Timor Leste had yet to meet challenges of globalization and complexities in the ASEAN environments, regarding the establishment of ASEAN Community in 2015. It is urgently considered that Timor Leste's membership may disrupt or even jeopardize the implementation of the ASEAN community (Costa, 2011) due to a very low level of economic development even below other ASEAN countries. The rejection of several ASEAN countries incrementally changed when Indonesia expressed its support for Timor Leste membership in ASEAN. Several ASEAN countries seemed to sing another tune and began to support Indonesia's direction. Indonesia's supporting speech removed the political obstacles of Timor Leste's accession to ASEAN (Wuryandari, 2011).

Indonesia also lobbied several times, for example, lobbied Malaysia to help restore Timor-Leste's internal conditions and to convince several 
countries that refused Timor Leste membership to accept Timor Leste's membership. Martin Natalegawa, Indonesian's Foreign Minister in Susilo Bambang Yudhoyono administration, revealed several times that Indonesia supported Timor Leste membership. The minister added that Timor Leste membership would provide positive benefits rather than negative impacts and Timor Leste was undeniably a part of Southeast Asia geographically and geopolitically (Republika, 2011).

Aside from lobbying and convincing ASEAN countries to accept Timor Leste membership, Indonesia also provided real assistances. Indonesia through its Ministry of Foreign Affairs (MOFA) appointed Agus Tarmizi as senior technical advisor to assist and facilitate technical assistances to the Ministry of Foreign Affairs of Timor Leste addressing to development of Timor Leste's human resources to prepare for membership in ASEAN (Tarmizi, 2009). These were so called "Strategic Plan System" focusing mostly on capacity building. Indonesia expected that these could help Timor Leste prepare diplomats to have adequate capacities at major ASEAN meetings (Wuryandari, 2011). Moreover, since the two countries maintained cordial relations, Indonesia had facilitated Timor Leste's leaders to be educated in Indonesia through various official trainings (Suarez, 2011).

Lately, in 2011 Timor Leste seemed to be highly eager to achieve ASEAN membership since Indonesia became the chair of ASEAN in 2011. Timor Leste submitted an application for ASEAN membership in the year of Indonesia's leadership in Southeast Asia. Timor Leste had high hopes for Indonesia as Chair of ASEAN to play its role and to use its influence in ASEAN to launch Timor-Leste's plan to become a member of ASEAN by taking consensus as soon as possible over Timor Leste's request.

\section{Economic and Military Conditions}

\section{Timor Leste's Close Economic Relations with ASEAN Countries}

From the beginning of its independence to some years away, Timor Leste had established trade relations (export and import activities) with 
several countries. Generally speaking, with these trade activities, Timor Leste benefited from increasing state revenues, providing millions of dollars in profits, fulfilling domestic needs and positively delivering more jobs and so on. The following data on Timor Leste's import from countries around the world based on regional organization in 2008-2010:

Chart 2. Timor Leste's Import Partners 2008-2010.

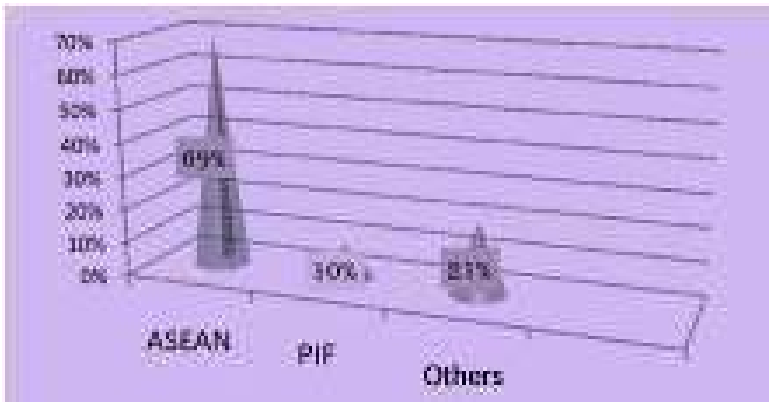

Source: Ministry of Financial of Timor Leste, 2011

The chart 2 shows that Timor Leste had undertaken import activities with countries from several regions. Compared to other countries based on regional organizations, ASEAN countries had been Timor Leste's main import partners (Indonesia, Singapore, Vietnam, Malaysia and Thailand) for three years before 2011. In 2008, imports with ASEAN countries reached $73 \%$ of Timor Leste's total import value. In those three years, ASEAN countries had dominated the total import value of Timor Leste with a percentage of around 69\% averagely. This means that ASEAN countries have become important partners and Timor Leste relied deeply on ASEAN countries in fulfilling the needs of Timor Leste's people. Compared to other 
countries based on regional organization, such as PIF, the total import value with these countries from this regional organization only accounted for around $10 \%$. Of many PIF member countries, it was unfortunately with only one country (Australia).

Chart 3. Timor Leste's Export to ASEAN, PIF, and Other Regions in \%

$17 \%$

$4 \%$

$69 \%$

ASEAN PIF Others

Source: Ministry of Financial of Timor Leste, 2011

Although the export value to ASEAN countries (in particular Indonesia, Singapura, Malaysia and Thailand) only reached $17 \%$ of Timor Leste's total export value, but if compared to the PIF countries (Australia and New Zealand) the value of Timor Leste's export with ASEAN countries was much higher because Timor Leste's exports to PIF countries only accounted for $4 \%$ of Timor Leste's total export value. 
The facts from chart 2 and chart 3 conclude that ASEAN countries have closer economic relations (export-import) with Timor Leste. In other words, Timor Leste and ASEAN countries have more dynamic relations compared to PIF countries. This also means that ASEAN countries play more important roles in Timor Leste's economy than with PIF countries. ASEAN countries bring about more benefits to meet Timor Leste's domestic needs and to provide more markets for Timor Leste's domestic products or commodities than PIF countries. With the established trade relations, Timor Leste may rationally try to maintain and even expand trade relations with ASEAN countries.

Looking at the prospect, from the potential number of captive markets of the two regions, ASEAN is clearly higher than PIF for huge population reaching more than 600 million people. While PIF was only resided around 30 million people (before 2011). Therefore, it was not surprising for Timor Leste to prioritize policies that are more inclined towards ASEAN. It includes Timor Leste's foreign policy which preferred to join ASEAN membership than PIF. By joining ASEAN membership, Timor Leste would strengthen its economic relations with ASEAN countries.

\section{Timor Leste's Military Capability Amidst Neighboring Countries}

Military conditions of a country can be generally assessed by referring to military capabilities comprising the number of troops and the annual military budget. Historically, Timor Leste's military force was formed in 2001 before its independence. This force is called the Forcas de Defesa de Timor Leste or commonly abbreviated as F-FDTL. The primary function of the F-FDTL is to maintain the stability of Timor Leste's security from both external and internal threats. As it also played a role in maintaining internal security stability, F-FDTL played an overlapping role with domestic police, Policia NacionaldeTimorLeste (PDTL).

As a matter of fact, until 2010 Timor Leste inhabited by 1.1 million people might be said to be vulnerable to air attacks because Timor Leste 
still did not possess air force troops and had yet to operate a single fighter aircraft (IISS, 2010). Timor Leste only possessed around 1332 active military personnel (IISS, 2011). It only increased a small number per year gradually. While the reserve personnel and paramilitary or auxiliary forces, Timor Leste only had a very small number, or it can be said it had not owned at all. With this small number, the forces were burdened heavy duties maintaining both internal and external territory.

The second indicator is military budget. The budget for the military sector is an important indicator in assessing the country's military strength. With its status as a newly independent country, Timor Leste still had a very low GDP which ranked 174 of 193 countries before 2011. However, the percentage of national budget of total GDP for military was quite big as compared big countries such as United States of America (4, 7\%), China (2.0\%) and Russia (3.9\%) (SIPRI, 2011). In 2008-2010, Timor Leste budgeted for $5.3 \%, 6.7 \%$ and $3.5 \%$ of GDP respectively for its military budget.

As a new country, it is important that Timor Leste assess its military capability at least with the surrounding countries. However, in realism perspective neighboring countries with greater military capability have the potential to pose a threat to the stability of Timor Leste's external security. To assess military capability Timor Leste may compare its own military capability with neighboring countries based on two indicators above (the number of troops and military budget) as follows:

Table 1. Timor Leste's Active Military Personnel in Comparison with Neighboring countries (2010) 


\begin{tabular}{|c|c|c|c|c|}
\hline Stale & Active nellitare & $\begin{array}{l}\text { Puerut } \\
\text { miliran }\end{array}$ & Rarumilian & That \\
\hline Thar Late & 112 & 9 & T) & $M$ \\
\hline Indirnenta & ILEkH: & -werita & 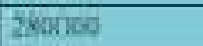 & पizhide \\
\hline Austribs & $\sin 23$ & 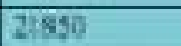 & in & Ackin? \\
\hline Maliygen & [TFDA] & 296360 & 2460 & 42494 \\
\hline Pерна N ugini & $31(0)$ & 0 & 9 & 7 (10010 \\
\hline Bugupur & 7150 & 36401 & 51ALA & 52:191 \\
\hline Thuifini & 305850 & 245000 & 113700 & 664560 \\
\hline Vistmem & 45 STCE & 5046000 & 40000 & S45ाWW \\
\hline $1 \sin$ & 25100 & a & Ixplatat & 129101 \\
\hline Rumbige & 14500 & (a) & 67I0 & नाभत्य \\
\hline Thunet & To-4I & THI & 2250 & 9451 \\
\hline Myanimar & 4060\% & 0 & Ionzes & 513250 \\
\hline PHipan & ISWhaj & Plowe & ARt40 & 311407 \\
\hline
\end{tabular}

Source: International Institute for Strategic Studies, 2011

Chart 4. Timor Leste's Military Budget in Comparison with Neighboring countries (2010)

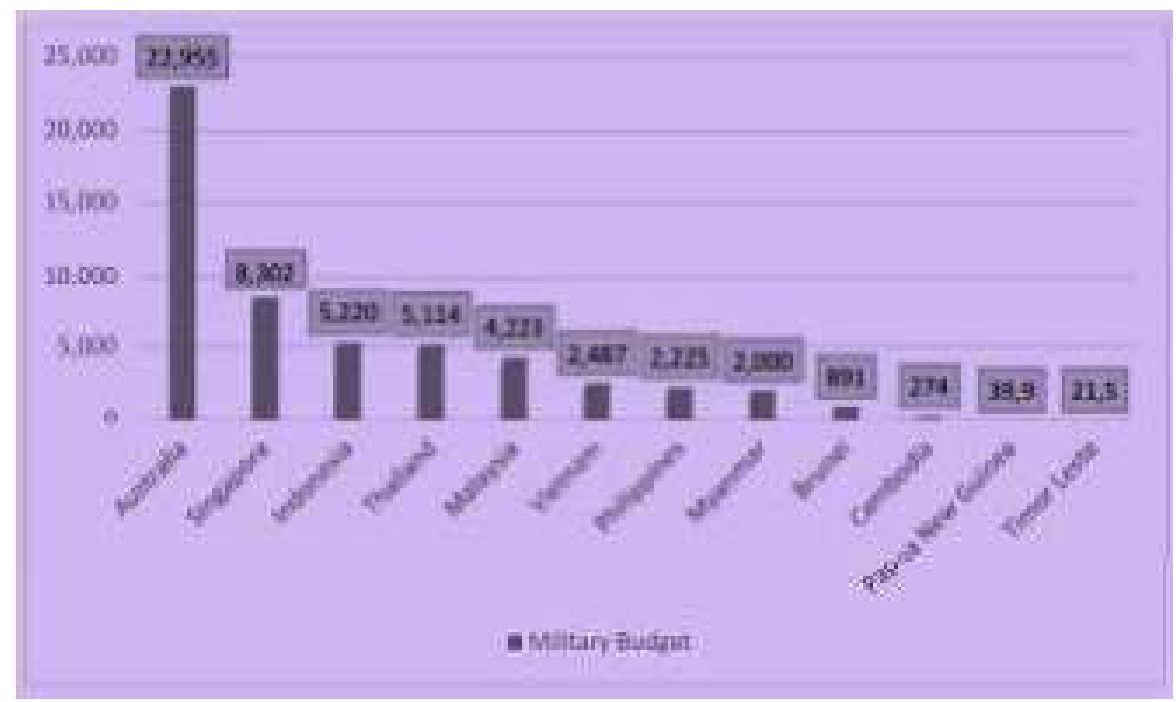

Source: International Institute for Strategic Studies, 2011 
Chart 4 Timor Leste points out that Timor Leste had the lowest number of troops and military budget among ASEAN countries and other countries around Timor Leste. With low military power, Timor Leste has more potential to be exposed by potential threats towards external stability from these neighboring countries. Moreover, Timor Leste is surrounded by two countries which had far greater military power, namely Indonesia and Australia. Security stability is important for all countries including the new nation like Timor Leste. When security stability is threatened, it often jeopardizes national interests of a country. It can be harmful for Timor Leste in the pursuit of its national interests in the future. Under this circumstance, Timor Leste necessarily improves its external security to assure its security stability.

Smith (2005) asserted the importance of security stability for new small states in military power. In order to improve or at least maintain its security stability, Timor Leste required to carry out three possible foreign policies; neutral policy, aligning with greater power or joining within the framework of collective security.

A neutral policy had been carried out by Timor Leste through several Timor Leste's actions. One of them was the primary Timor Leste's diplomacy called "hello amigo ba ema hotu no la halo inimigu ba ema ida" or to make friends with all of them and make no enemies (Ximenes, 2011). Timor Leste claimed that this policy was capable of at least maintaining the stability of Timor Leste's external security. By making everyone friends and no hostile to anyone lessened the possibility of employing the power from neighboring countries to Timor Leste.

The next policy reference is joining an alliance with a greater power. An alliance with a greater power (powerful state) may increase Timor Leste's external security because powerful state can provide Timor Leste with protection from military external threats. Herewith, there are two important things, it keeps in mind. First, Timor Leste can be secured from 
other countries militarily because the existence of powerful state can help Timor Leste protect from external threat. Yet, this is only in the context of conventional or military threats whereas non-conventional or non-military threats are mostly beyond the scope of the alliance. Timor Leste still has tangible potentials to remain threatened or vulnerable to non-military threats such as terrorism, transnational drug, human trafficking etc.

The third option is collective security. Collective security is another rational choice for Timor Leste. Joining the collective security mechanism seemed to be realized through its decision towards ASEAN membership. Timor Leste's external security stability will be oriented towards the ASEAN frameworks that one of the points is ASEAN countries are not allowed to attack one another. They use peaceful means such as dialogue and consultation on emphasis in case of difference, conflict and dispute as stipulated in ASEAN way (Yani \& Montratama, 2018). By becoming a member of ASEAN, Timor Leste will be more increasingly secured from military attack of neighboring countries. If Timor Leste is attacked by a country outside ASEAN (such as Australia or New Zealand) then all ASEAN countries may help Timor Leste to prevent or even fight the aggressor country since the important principle of collective security is all against one.

Joining ASEAN membership, Timor Leste has rationally sought to strengthen or improve its external security stability. In the context of the security dimension, Timor Leste will obtain a complete external security both security from conventional threats and non-conventional threats. In short, Timor Leste will rely more on ASEAN security which has a security community framework through the ASEAN Security Community (ASC) which was initiated to embark in 2015 (Luhulima, 2008). Timor Leste will work with ASEAN countries to prevent and reduce potentials for Timor Leste's external security threats from conventional and non-conventional threats. Timor Leste's external security stability will increase and in a line with this, Timor Leste has a big opportunity to reduce the military budget 
for external security stability because it is logically shared with other ASEAN countries.

\section{CONCLUSION}

Timor Leste's foreign policy orientation changed from PIF to ASEAN after its 2002 independence. Applying model of foreign policy decision making, the authors found that there were several international factors that underlie Timor Leste to join ASEAN membership. This can be seen from two variables namely international context and economic and military conditions of Timor Leste. In the international context, Timor Leste joined ASEAN membership due to ASEAN's attractiveness as a prospective regional organization and strong support from Indonesia as an influential country in the Southeast Asia region through lobbying efforts, moral support in international forums, and trainings. In terms of economic condition, close economic relations with ASEAN countries that can be seen from trade activities (export-import) became an important factor in fulfilling Timor Leste's economic interest as well as being a catalyst for joining ASEAN membership. The last, the very low military capability of Timor Leste compared to neighboring countries, made Timor Leste need to join regional organization such as ASEAN to more secure external security both from conventional and non-conventional threats in the mechanism of collective security provided by ASEAN security framework.

\section{REFERENCES}

Ananda, Candra.F. 2019. Peran ASEAN pada Ekonomi Dunia. accessed from https://feb.ub.ac.id/id/peran-asean-pada-ekonomi-dunia.html Annual Report of External Trade Statistics 2008-2011, Ministry of Finance of Timor Leste. Dili.

ASEAN. Bali Concord II. 2012. accessed from https://asean.org/?static_post=declaration-of-asean-concord-ii-baliconcord-ii

ASEAN. ASEAN Investment Report 2011. 2011. accessed from http://investasean.asean.org/files/upload/ASEAN\%20Investment\%2 OReport\%202010-2011.pdf 
Asian Development Bank Institute (ADBI). 2014. ASEAN 2030: Toward a borderless Economic Community. Accessed from https://www.adb.org/sites/default/files/publication/159312/adbiasean-2030-borderless-economic-community.pdf

Azhari, Noordin. 2011. ASEAN and East Timor: Family Someday? In ASEAN Matters! Reflecting on The Association of Southeast Asian Nations. World Scientific: Singapore.

Coplin, William D. 2003. Pengantar Politik Internasional; Suatu telaah teoritis. Bandung: CV.Sinar Baru.

Evans, Graham \& Newnham, Jeffrey. 1998. The Penguin Dictionary of International Relations. London: Penguin Books.

International Institute for Strategic Studies (IISS). The military balances 2010. accessed from http://www.iiss.org

Horta, Ramos. 2000. East Timor and Region, paper presented on Seminar Trends in Southeast Asia, December 18th 2000 , Institute of Southeast Asian Studies, Singapura.

Joseph, Abraham \& Hamaguchi, Takako. 2014. Timor Leste: The History and Development of Asia's Newest Nation. Lexingtong Book.

Luhulima, C.P.F. 2008. Masyarakat Asia Tenggara menuju komunitas ASEAN 2015. Yogyakarta: Pustaka Pelajar.

Miller, John. Agence France Press. 26 Februari 1999. East Timor Leste South Pacific Forum ahead of ASEAN. accessed from http://www.etan.org/et99/july/25-31/26etprefer.htm

Nau, Henry R. 2012. Perspectives on International Relations: Power, Institutions, and Ideas (Sixth Edition). Los Angeles: CQPRESS.

Organization for Economic Cooperation and Development (OECD). 2009. Shaping Policy Reform and Peer Review in Southeast Asia Integrating Economies Amid Diversity. accessed from http://www.oecd.org/regional/searf2009/42000050.pdf

Putnam, R. D. 1988. Diplomacy and Domestic Politics: The Logic of TwoLevel Games. International Organization. Vol. 42, No. 3 (Summer).

Republika. 2011. Indonesia Dukung Timor Leste Jadi Anggota ASEAN. accessed from https://internasional.republika.co.id/berita/internasional/internasio nal/158865/indonesia-dukung-timor-leste-jadi-anggota-asean

Singham, Gerald \& Harihara, Soumya. 2012. Competition laws in ASEAN: A South-East Asian perspective, Rodyk \& Davidson LLP. accessed from https://www.lexology.com/library/detail.aspx?g=6c532563-816b4507-ade6-bfbd13a3f4ab

Smith, Anthony L. 2005. Constraints and choices: East Timor as foreign policy Actor. New Zealand Journal of Asian Studies, Vol.7. (June). Soares, Dionisio B \& Costa, Helder. 2003. Timor-Leste facing regional dilemma: East Timor and Indonesia Action Network. accessed from http://etan.org/timor.html 
Stockholm International Peace Research Institute (SIPRI). Military Expenditure 2011. accessed from http://www.indexmundi.com/facts/timor-leste\#PublicSector- Defencse $\%$ arms trade

Strating, Rebecca. 2019. The Post-Colonial Security Dilemma: Timor-Leste and the International Community. ISEAS Publishing: Singapore.

Suarez, Juan. 2011. East Timor: ready to join ASEAN? European Institute for Asia Studies. accessed from http://www.eias.org/sites/.../EIAS_2011-AprMay_EastTimor_ASEAN.pdf>

Swastia, S.A. 2016. Diplomasi Timor Leste Bergabung Dalam Keanggotaan Tetap ASEAN. IJOM FISIP. Vol. 3. No. 2 (October).

Tarmizi, Agus. 2009. The prospect of ASEAN membership in ASEAN, paper presented on Roundtable Discussion by BPPK, May 9'th 2009, Ministry of Foreign Affairs of Indonesia.

Thejakartapost. February 4th, 2009. Timor Leste launches ASEAN Secretariat. p. 3

Wuryandari, Ganewati. (2011). East Timor's membership in ASEAN: Prospects andchallenges, LIPI (Lembaga Ilmu Pengetahuan Indonesia) accessed from http://www.aseancenter.org.tw/upload/files/OUTLOOK_003_02.pdf

Yani, Yanyan Mochamad \& Montratama, Ian. 2018. Indonesia and ASEAN in 2025: a Political and Security Perspective. Dinamika Global. Vol.3. No. 2 (December).

Xavier, Hermenegildo. 2016. Upaya Timor Leste Untuk Bergabung dalam ASEAN. Yogyakarta: Universitas Gadjah Mada.

Ximenes, Alarico d.Costa. 2012. Kepentingan dan diplomasi Timor Leste di ASEAN. Yogyakarta: Universitas Gadjah Mada. 